\title{
Conservationist Leadership Style and Corporate Culture in Indonesian Private Banks
}

\author{
Kusmuriyanto \\ Universitas Negeri Semarang, L2 Building of Faculty of Economics,Sekaran Campus, 50229, Semarang, \\ Indonesia \\ Lyna Latifah \\ Universitas Negeri Semarang, L2 Building of Faculty of Economics,Sekaran Campus, 50229, Semarang, \\ Indonesia \\ Nurdian Susilowati \\ Universitas Negeri Semarang, L2 Building of Faculty of Economics,Sekaran Campus, 50229, Semarang, \\ Indonesia
}

\begin{abstract}
The purpose of this study is to determine the direct and indirect influences of conservationist leadership styles andcorporate culturetoward budgetary participation and managerial performance. The population of the studyis the managers and employees of private banks in Semarang. Quantitative analysis was done through primary data collection using questionnaire. The collected data are then analyzed using path analysis techniques. Based on the first result of the study, the conservationist leadership styles successfully moderate the variable of budgetary participation on the managerial performance of private banks. The most appropriate conservationistleadership styles for the private banks managers are open and humanist styles. Second, corporate cultureof the private banks successfully moderatesthe budget participation on the managerial performance. The elements forming thecorporate culture will encourage the creation of good managerial performance. Third, the budgetary participation influences the managerial performance. Therefore, all employees should be involved in the budgeting to obtain the best and the most precise budget to be used as a guidelines and reference for the private banks in running their business activities.
\end{abstract}

Keywords: conservationist leadership styles; corporate culture; budgetary participation; managerial performance of private banks

DOI: $10.7176 / \mathrm{EJBM} / 12-3-03$

Publication date: January $31^{\text {st }} 2020$

\section{Introduction}

The increasing competitivenesswhich is in line with the growth of the business resulted in tremendous changes in marketing, finance, and resourcesmanagement, so that the business entities should be able to maintain their viability (survival) by always showing effective and efficientperformancereferring to E3 (economy, efficiency, and efectivity). In the future,the performance of the business entities do not only refer to E3, but alsoE4 (economy, efficiency, efectivity, and earth). The managers' ability to manage their business entities can be regarded as the managerial performance.

In the business entities, the managerial performance is associated with its participation in the preparation of the budget. Participation in the preparation of the budget is the managers' level of involvement and influence in the budgeting process of a department or its subdivision, both periodically and annually (Brownell, 1982). This study focuses on the private banks, especially those located in the former residency of Semarang. The rual banks serve as a business entity that raises and channels public funds, and they should be able to support the modernization of the countryside and provide maximum services for small entrepreneurs. Therefore,it is strongly required good managerial performance. Bangun (2009) defined the managerial performance asa processof effective managerial activities, starting from planning, budgeting, administration, reporting, accountability and supervision.

One leadership aspect that is considered important and possiblyinfluences the managerial performance is leadership styles. The leadership styles are closely related with the methods used by managers to organize and influence their employees in order to achievegoals of the company. Based on manyleadership styles existing today, it should be considered conservationists leadership style. The conservationist is a leader who has strong awareness and commitment for environmental sustainability both in natural and socio-cultural environment. Moreover, the success of the managerial performance is also closely related with the corporate culture of the company. Cultural organization has a strategic role for the success of the organization to establish managerial performance and encourage the organization to grow and develop as expected. The role of corporate culture itself is as a means to determine the direction of the organization, to direct what should and should not do, and how to 
manage and allocate the organizational resources to deal with internal and external problems. Based on the background described, it is alleged thatconservationist leadership styles will significantlyinfluence the preparation of the budget and managerial performance. In addition, the corporate culture is assumed to influence the preparation of the budget and managerial performance.

\section{Literature Review}

\subsection{Contingency Theory}

Contingency theory explains that effective groups depend on the match between the conservationist leadership styles of the managers that interact with their subordinates, so that the situation becomes the controller and influences the leaders. In the budgetary participation, the use of contingency theory has long been a concern to the researchers. Based on the results of previous studies, a contingency theory may influencethe budgetarytoward the performance of local government officials. The participation of local government officials in the budgetary preparation can hone their knowledge about the budget and provide beneficial information to the public about the budget prepared by the government. Participatory budget will increase the participation of the executive, improve the level of aspiration, and increase motivation which will ultimately bring positive influences on the managerial performance.

\subsection{Managerial Performance}

Performance means the quantity and quality of the work completed by an individual, group or organization. Bangun (2009) stated that the performance of the government officials is a process of effective managerial activities, starting from planning, budgeting, administration, reporting, accountability and supervision.

\subsection{Conservationist Leadership Styles}

Conservationist leadership styles arean individual'smodels or ways to influence other individuals/groups toward the achievement of a vision or set goals (Robbins, 2009). Each leader's conservationist leadership styles are different, and the most appropriateconservationist leadership styles areopen and more humanist leadership, it refers to consideration. According toAs'ad (2011), an individual'sconservationist leadership styles aredescribed as having characters likethe sun, wind, moon, fire, earth, sky, ocean, and stars.

\subsection{Corporate culture}

Corporate culture is a form of beliefs, values, and ways that can be learnt to cope and live within an organization. The corporate culture tends to be realized by the membersof the organization. Robbins (2009) explained that the corporate culture is a value system held and carried out by its members, so that such thing can distinguish one organization to others. Group behavior is all activities carried out by two or more individuals who interact and influence each other and are interdependent to generate long-term positive achievement for selfgrowth. Meanwhile, Robbins (2009) explained that the theory of group behavior explains the functions of the interaction between individuals and their environment.

\section{Research Methodology}

\subsection{Sampling Methods}

The populationand samplefor this research arethe managersand employess of the private banks located in the former residency ofSemarang,taken using simple random sampling technique. The total of sample are 130 respondents.

\subsection{Research Variables}

There are 4 (four) variablesused in this research.

1) Managerial performance (Y)

The managerialperformance (job performance) is the manager's ability in carrying out managerial tasks that support the effectiveness of his business entity. This instrument was developed by Mahoney et al., (1963), consisting of 9 (nine) questionitems.

2) Budgetary articipation (X1)

The indicators of budgetary participation variables include (1) manager's involvement; (2) logical level of reasons delivered by the manager's boss; (3) how often the manager invites his/her boss to discuss something together, (4) how much the influence of the manager; (5) how much the manager have contributed; and (6) how often the boss of the manager asks the opinionsorsuggestionsfrom the manager during thepreparation of the budget in which he is responsible for it.

3) Conservationist leadership styles (X2)

Leadership is an indiviudal's ability to influence and motivate other people to and make others to be able to contribute for the sake of effectiveness and success of the organization. This variable adopts the measurement 
instruments used Robbins (2009) with alternative answers ofthe questions consisting of 5-pointLikert scale.

4) Corporate culture (X3)

According to Freemont and Rosenzweig in Robbins (2009), the corporate culture is a system of valueand belief held together to interact betweenthe people within a company; anorganizational structure and supervision system to generate behavioral norms.

3.4. Data Collection Techniqueand Analysis Method

The data collection technique used in this research is questionnaire. The data analysis method used is Path Analysis.

\section{Results}

There are four variables that will be tested in this research, i.e. budgetary participation, conservasionist leadership styles, corporate culture, and managerial performance. There are sixpath parameters to be identifiednamelyp 1 to p6 and 3 error parameters, e1 to e3. To view these parameters, there are three stages of regression that will be conducted; first, the influence ofbudgetary participationtoward managerial performance through conservationist leadership styles; second, the influence of budgetary participationtowardmanagerial performancethrough corporate culture, and; third, the influence of budgetary participationtowardmanagerial performance. Based on the results of the regression, it is then obtained partialpathcoefficient values as follows:

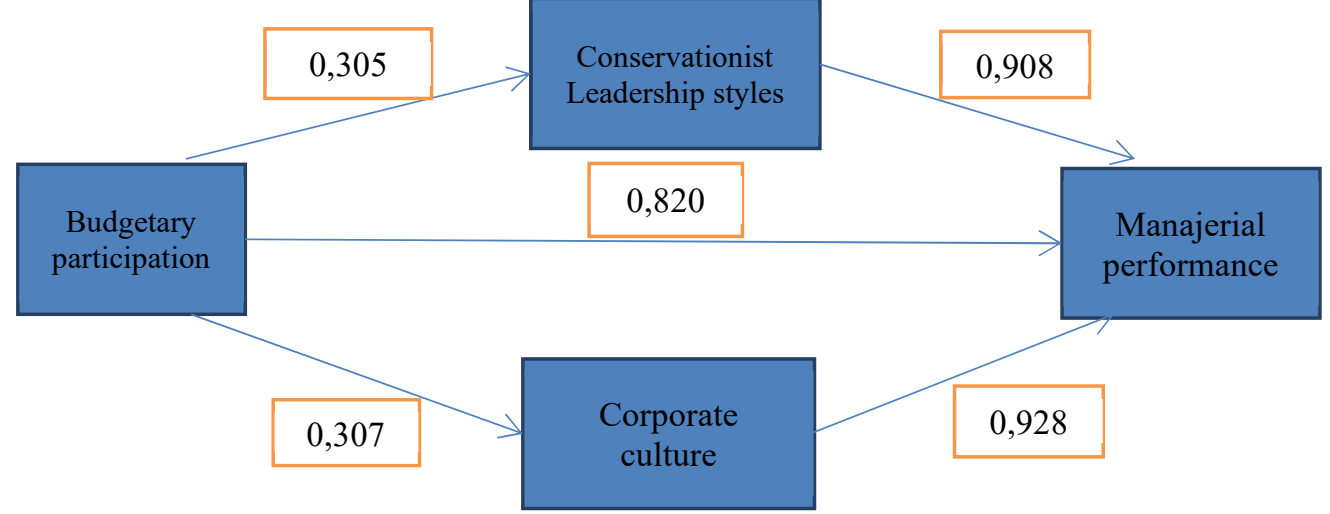

Figure 1. Path Analysis

Based on the results of the research, the indirect influenceof the budgetary participation toward the managerial performance through theconservationist leadership styles is equal to $0.305+0.908=12.13$, meaning that theconservationist leadership styles can be the moderating variable on the managerial performance. Meanwhile, the indirect influence of the budgetary participation toward the managerial performance through the corporate culture is $0.307+0.928=11.25$,so that thecorporate culture can moderate the budgetary participation on the managerial performance. The last is the direct influence of budgetary participation toward the managerial performance, as much as 82.00 .

\section{Discussion}

\subsection{Influence ofBudegtary ParticipationtowardManagerial Performance throughConservationist Leadership Styles}

Based on the results of the research, the conservationist leadership styles ofprivate banks managerssuccessfully moderate the budgetary participation toward the managerial performance. The budgetary participation involves the managers of the private banks in determining budgetary purposes that become their responsibilty. The results of this study indicate that openness and humanistconservationist leadership styles have a positive impact on their motivation in the preparation of the budget. The managers' conservationist leadership styles can moderate theirmanagerial performance. In this study, the most prominent leadership style mostly performedby the private banks managers is the open styleor encouraging the employees and subordinatesto beoutstanding persons.

The private banks managers give opportunities to the employees to express their opinions, do consensus, listen to any positive ideas and opinions, know their personalities, work in groups, and performguardianship roles. This study is consistent with the research by Kagaari (2011)who stated that the influence of subordinates is a major factor that distinguishes between participative and non-participative budgeting. Meanwhile, this study generates contrarily results withBiduri (2011) and Rudhianto (2010) who found that there was no significant effect of the conservationist leadership styles in moderating the relationship between budgetary participation and performance.

\subsection{Influence ofBudgetary ParticipationtowardMangerial PerformancethroughCorporate Culture}

Based on the results, the corporate culturesuccessfullymoderatesthe budgetary participation toward the managerial performance of the private banks. Good forming elements of the corporate culture will encourage the creation of 
good managerial performance. The involvement of the employees and managers in the budgeting process,starting from planning, implementation, and evaluation will encourage the company to develop better. Moreover, a comfortablecorporate culture can motivate each employee to work optimally in achieving the business goals.

\subsection{Influence of Budgetary ParticipationtowardManagerial Performance}

Based on the research results, the budgetary participation influencesthe managerial performance of the private banks. The budgetary participation plays an important role for the implementation of business activities. Tapatfeto (2013) argued that participation can bring a sense of confidence and motivation from lower-level managers to contribute to the budgeting process. The budgetary participation will result in a proper budget that can be the main guidance and reference for the company in running its business programs.Meanwhile, the budgeting process is an important and complex activity, and it can affect the attitudes and behavior of the members of the organization functionally and dysfunctionally. To prevent dysfunctional impacts of the budget, it is strongly required the subordinates' involvement. The subordinates' participation in the budgeting processmakes it for the managers (as the subordinates) to negotiate with their employers about the possibility of budget targets that can be achieved Brownell (1982).

Budgetary participation is expected to improve the managerial performance of the private banks, i.e. when the goals setare approved participatively, and the employees will internalize these goals and each of them will uphold personal responsibility to achieve the goals through their involvement in the budgeting process. According to Brownell (1982), participation is generally considered as a managerial approach to improve the performance of the organization's members. Brownell (1982) conducted a study on the middle-class managers to measure the relationship between budgetary participation and managerial performance, and they found that high participation in the budgeting will improve the managerial performance significantly.

\section{Conclusions}

Based on the results of the study, it can be concluded that the conservationist leadership styles of theprivate banks managerssuccessfully moderatethe budgetary participation toward the managerial performance. The most appropriate conservationist leadership styles are openness and humanist. Thecorporate culture of the private bankshas also been proved capable of successfully moderating the budgetary participation toward the managerial performance. Good forming elements ofthecorporate culture will encourage the creation of good managerial performance. Meanwhile, the budgetary participation significantly influences the managerial performance of the private banks. Therefore, all employees should be involved in the budgeting process to generate a budget that can be used as a proper guidelines and reference for the company in running its business activities.

To develop the results of this study, further research shouldexamine bothstate-owned and private banks that have more complex business activities, so that we can distinguish the types of conservationist leadership styles thatexiston them. The further research should also assess other variables such as religious values, and managers'attitudes, confidence, and trust in running the business to determine their managerial performance.

\section{References}

As'ad, et al.(2011). "Studi Eksplorati Konstrak Kepemimpinan Model Jawa": Asta Brata. Jurnal Psikologi, Volume 38, No 02, Halaman (228-239)

Bangun, Andrias.(2009)."Pengaruh Partisipasi Dalam Penyusunan Anggaran Kejelasan Sasaran Anggaran Dan StrukturDesentralisasiTerhadapKinerjaManajerial SKPD DenganPengawasan Internal Sebagai Variabel Pemoderasi (StudiKasusPadaPemerintahan Deli Serdang), Thesis UNSUT Medan

Biduri,Sarwenda.(2011)."Pengaruh Partisipasi Penyusunan Anggaran terhadap Kinerja Manajerial dengan Variabel Pemoderasi Gaya Kepemimpinan dan Komitmen Organisasi pada Pemkab Pekalongan"..JurnalAkuntansi, ManajemenBisnisdanSektorPublik (JAMBSP). Vol. 8, No. 1 (41-56)

Boujelbene,Mohamed Ali, and HabibAffes.(2012). "The Effect of Environmental Uncertainty and Budgetary Participation on Performance and Job Satisfaction Evidence FromThe Hotel Industry".African Journal of Hospitality, Tourism, and Leisure. Vol. 2 (2), ISSN: 2223-814X

Brownell, Peter.(1982). "A Field Study Examination of Budgetary Participation and Locus of Control". The Accounting Review, October, 766-777.

Cheng, Min-Tsung.(2012). "The Joint Effect of Budgetary Participation and Broad-Scope Management Accounting Systems on Management Performance". Asian Review of Accounting, Vol. 20, No 3

Haryanti, Ida Binti Mohd Noor, and Radiah Othman.(2012). "Budgetary Participation: How It Affects Performance And Commitment".Accountancy Business and the Public Interest

Kagaari, James. (2011). "Performance Management Practices and Managed Performance: The Moderating Influence of Organisational Culture And Climate In Public Universities In Uganda".Measuring Business Excellence. Vol. 15 Iss 4 pp. 36 - 49

Mahoney, et al. (1993). “Development of Managerial Performance: A Research Approach”. Clincinnati: South 
Western Publishing

Robbins, Stephen P. dan Judge, Timothy A., (2009). “Organizational Behavior.13th Edition”. Pearson Education, Inc., Upper Saddle River, New Jersey.

Rudhianto,Hermawan.(2010). "Pengaruh Komitmen Organisasi dan Gaya Kepemimpinan terhadap Hubungan antara Partisipasi Anggaran dan Kinerja (Studi Empiris di Universitas Sebelas Maret)".Tesis.Universitas Sebelas Maret.

Tapatfeto,Jasintha Dessy. (2013). “Analisis Komitmen Tujuan dan Partisipasi Penyusunan Anggaran terhadap Kinerja Manajerial".Jurnal Akuntansi Multiparadigma. Vol. 4, No. 3 (495-507).

Yahya, Mohd Nor. (2008). "Budgetary Participation and Performance:Some Malaysian Evidence”. International Journal of Public Sector Management, Vol. 21 No. 6

Yukl, G.(2010). “Leadership in Organization:7thEdition. New Jersey”: Pearson-Prenctice Hall. 